\title{
HUBUNGAN ANTARA PERILAKU ASERTIF DENGAN KECENDERUNGAN MENJADI OBJEK PERUNDUNGAN PADA SISWA BERASRAMA
}

\author{
Zhafira Mardhatillah Maulia, Basti Tetteng, Andi Nasrawaty Hamid
}

Fakultas Psikologi, Universitas Negeri Makassar. Indonesia

Email: zhafiramaulia@gmail.com, basti@unm.ac.id, andi.nasrawati@unm.ac.id

\begin{abstract}
Bullying is one form of delinquency that is often found among adolescents, especially in schools. Bullying is an act that intimidates objects that are considered weaker. Individuals less assertive and not assertive tend to be objects of bully. Assertive behavior is expressing self directly, honestly, positively to fight for personal rights without neglecting the rights of others to meet needs or express feelings without anxiety. This study aims to look at the relationship between assertive behavior and the tendency to be objects of bully to boarding students. The method used in this research is quantitative. The respondents of this study were 205 teenage students, 12-17 years old from boarding schools A and high school B. The analysis technique used in this study was the Spearman rank correlation. The results showed that there was a negative relationship between assertive behavior with a tendency to be the object of bully in boarding students ( $p=-$ $0.22 r=0.002$ ). This means that the higher assertive behavior, the lower tendency to be object of bully in boarding students. The results of this study an evaluation for adolescents to develop assertive behavior to avoid bullying and as a basis for schools and adolescent environments for bullying prevention program.
\end{abstract}

Keywords: objects of bullying, assertive behavior, boarding student

\begin{abstract}
ABSTRAK
Perundungan merupakan salah satu bentuk kenakalan yang kerap ditemukan dikalangan remaja terutama di sekolah. Perundungan merupakan tindakan yang dengan sengaja mengintimidasi objek yang dianggap lebih lemah. Individu yang kurang tegas dan tidak asertif cenderung menjadi objek perundungan. Perilaku asertif merupakan tindakan mengekpresikan diri secara langsung, jujur, positif dan tegas untuk memperjuangkan hak pribadi tanpa mengabaikan hak orang lain untuk memenuhi kebutuhan atau mengungkapkan perasaan tanpa mengalami kecemasan. Penelitian ini bertujuan untuk melihat hubungan antara perilaku asertif dengan kecenderungan menjadi objek perundungan pada siswa berasrama. Metode yang digunakan dalam penelitian ini adalah kuantitatif. Responden penelitian ini adalah 205 siswa usia remaja yakni 12-17 tahun dari sekolah berasrama pesantren A dan SMA B. Teknik analisis yang digunakan dalam penelitian ini adalah Spearman rank correlation. Hasil penelitian menunjukkan bahwa ada hubungan negatif antara perilaku asertif dengan kecenderungan menjadi objek perundungan pada siswa berasrama $(\mathrm{p}=-0,22 \mathrm{r}=0,002)$. Artinya semakin tinggi perilaku asertif maka semakin rendah kecenderungan menjadi objek perundungan pada siswa berasrama. Hasil penelitian ini dapat menjadi bahan evaluasi bagi remaja agar lebih mengembangkan perilaku asertif untuk menghindari terjadinya perundungan serta sebagai dasar bagi sekolah dan lingkungan remaja untuk membuat program pencegahan terjadinya perundungan.
\end{abstract}

Kata Kunci: objek perundungan, perilaku asertif, siswa berasrama 


\section{PENDAHULUAN}

Masa remaja merupakan salah satu tahap perkembangan yang sangat penting untuk diperhatikan baik bagi remaja, orang tua, ataupun pihak sekolah. Santrock (2003) mengemukakan bahwa masa remaja adalah tahap perkembangan yang mewakili proses transisi dari masa anak ke dewasa. Banyak perubahan yang dialami pada masa remaja baik berupa perkembangan fisik, kognitif maupun sosial yang ditandai dengan perkembangan fungsi seksual, proses berpikir dan sosial emosional. Hurlock (1980) mengemukakan bahwa masa remaja berada pada rentang usia 13 atau 14 tahun sampai pada usia 18 tahun.

Hurlock (1980) mengemukakan bahwa terdapat beberapa tugas perkembangan remaja diantaranya mencapai hubungan baru yang lebih matang dengan sebayanya, mencapai peran sosial, menerima keadaan fisik dan menggunakan tubuh secara efektif, mengharapkan dan mencapai perilaku sosial yang bertanggung jawab, mencapai kemandirian emosional. Sebagian besar remaja menjalani banyak proses untuk mencapai tugas perkembangannya masing-masing namun dalam prosesnya tidak semua terpenuhi dan dicapai dengan cara yang baik. Beberapa remaja terlibat dalam kasus kenakalan berupa pencurian, penyalahgunaan obat, hingga kekerasan. Salah satu bentuk kekerasan yang sering ditemukan pada remaja adalah perundungan di sekolah.

Perundungan merupakan salah satu bentuk kenakalan yang kerap ditemukan dikalangan remaja terutama di sekolah Olweus (2004) mengemukakan bahwa perundungan merupakan perilaku agresif yang dilakukan individu atau sekelompok orang terhadap orang lain secara berulang. Coloroso (2007) menjelaskan perundungan dalam konteks pendidikan terutama di sekolah sebagai perilaku agresif secara berulang oleh individu atau kelompok yang memiliki kekuatan atau kekuasaan dengan tujuan menyakiti siswa yang lebih lemah. Perundungan yang terjadi secara berulang mempengaruhi proses perkembangan remaja di sekolah hal ini karena sekolah merupakan salah satu lingkungan sosial yang dekat dengan remaja. Hasil wawancara yang dilakukan oleh Karyanti, Atmoko, dan Hitipeuw (2015) dengan konselor SMA Y Palangkaraya pada tanggal 19 Agustus 2013 menemukan bahwa selama dua bulan terakhir terdapat 14 siswa kelas $\mathrm{X}$ yang berhenti dari sekolah tersebut karena mendapatkan perlakuan perundungan dari senior di sekolah.

Penelitian yang dilakukan oleh Putri, Nauli, dan Novayelinda (2015) pada 83 remaja SMA Negeri 7 Pekanbaru 
menemukan bahwa sebagian besar perundungan terjadi berupa kekerasan fisik sebesar $55,4 \%$, perundungan verbal sebesar $26 \%$ dan perundungan psikologis sebesar $18,1 \%$. Pada hasil penelitiannya ditemukan bahwa mayoritas remaja yakni $63,7 \%$ memiliki perilaku perundungan yang tinggi pada iklim sekolah yang kurang baik. Iklim sekolah yang dimaksud adalah lingungan belajar yang kurang mendukung, manajemen perilaku dan hubungan personal antar siswa dan antar guru yang kurang baik.

Iklim sekolah yang baik memiliki sumbangsi dalam prestasi dan memaksimalkan perkembangan psikologis siswa. Setiap sekolah memiliki sistem untuk menstimulasi kemampuan dan potensi siswa. Rasyid (2012) mengemukakan bahwa sekolah berasrama membantu siswa mengembangkan kemampuan pengambilan keputusan secara mandiri, rasa tanggungjawab, dan kemampuan adaptasi terhadap lingkungan baru. Siswa yang tinggal di asrama memiliki waktu interaksi yang lebih banyak dengan teman dan senior diasrama. Kemampuan penyesuaian diri dan adaptasi dilingkungan asrama membantu siswa untuk membangun hubungan yang baik dengan senior dan teman di asrama. Disisi lain jika siswa tidak memiliki kemampuan penyesuaian diri dan adaptasi yang baik maka cenderung akan menjadi objek perundungan. Perlakuan intimidasi biasanya terjadi diluar jam sekolah atau tanpa pengawasan pihak sekolah.

Hasil penelitian yang dilakukan oleh Pratiwi dan Sari (2017) pada siswa sekolah berasrama di Banda Aceh pada tahun 2017 menemukan presentase sebesar 66\% dari 97 responden mengalami perundungan di lingkungan asrama. Sebanyak 64 siswa mengalami perundungan fisik, 56 siswa mengalami perundungan verbal dan 59 siswa mengalami perundungan relasional. Hasil penelitian ini juga menjelaskan bahwa siswa laki-laki lebih banyak menerima perundungan fisik dibandingkan dengan siswa perempuan. Bentuk perundungan fisik yang paling banyak terjadi yaitu barang diambil dan tidak dikembalikan lagi yakni sebanyak 45 responden. Bentuk perundungan verbal yang paling tinggi frekuensinya adalah diejek yang berhubungan dengan fisik yakni sebanyak 53 responden. Bentuk perundungan relasional dengan frekuensi tertinggi yaitu dilihat dengan tatapan tidak suka yakni 60 responden

Perilaku perundungan hanya akan terjadi jika melibatkan dua pihak yakni pelaku dan korban. Setiap pihak memiliki karakteristik yang dapat diamati, baik sebagai pelaku ataupun korban perundungan. Arif dan Wahyuni (2017) 
mengemukakan bahwa pelaku perundungan biasanya memiliki kemampuan fisik yang lebih dibandingkan teman sebayanya atau korbannya. Pelaku perundungan lebih cenderung mendominasi, agresif terhadap teman sebaya dan orang dewasa, lebih impulsif dan susah mengontrol diri serta tidak mau menaati norma sosial yang berlaku. Berbanding terbalik dengan korban perundungan yang cenderung kurang asertif, gampang didominasi atau cenderung mengikuti perintah, serta merasa rendah diri. Anak dengan perilaku dan karakteristik serupa sangat berkemungkinan ditemukan di lingkungan berasrama yang membutuhkan kemampuan adaptasi yang baik. Penelitian yang dilakukan oleh Meilena dan Suryanto (2015) pada 56 siswa kelas VII menemukan bahwa terdapat hubungan positif antara perilaku asertif dengan kecenderungan terhindar dari tindakan perundungan. Semakin asertif siswa maka semakin tinggi kecenderungan siswa untuk terhindar dari tindakan perundungan.

Hurlock (1980) mengemukakan salah satu tugas perkembangan remaja adalah mencapai perilaku sosial yang bertanggung jawab. Tugas perkembangan ini berkaitan dengan interaksi remaja dengan teman sebaya. Salah satu perilaku sosial yang dikembangkan remaja agar dapat diterima dalam kelompok adalah perilaku asertif.
Atkinson (1997) mengemukakan bahwa asertif merupakan kemampuan komunikasi untuk mempertahankan hak pribadi tanpa melanggar hak orang lain. Sriyanto, Abdulkarim, Zainul, dan Maryani (2014) mengemukakan bahwa perilaku asertif bermanfaat bagi remaja untuk kemudahan bersosilisasi di lingkungan, menyelesaikan masalah secara efektif, dan menghindari konflik karena bersikap terus terang kepada orang lain. Novalia dan Dayakisni (2013) mengemukakan bahwa individu dengan sikap asertif yang rendah memiliki banyak kecemasan dan ketakutan serta tidak mampu untuk mempertahankan hak pribadinya. Korban perundungan kurang mampu menunjukkan perasaannya atau menolak perlakuan perundungan karena ketakutan bahwa pelaku akan menambah tindakan perundungan.

Hasil kuesioner terbuka yang diberikan oleh peneliti terhadap siswa pada dua sekolah berasrama di kota Makassar menemukan bahwa beberapa siswa memilih diam dan sabar ketika mendapatkan perlakuan tidak menyenangkan. Responden memilih diam karena jika melawan akan menambah masalah. Selain itu responden memilih diam karena merasa kurang percaya diri sebagai junior dan hanya bisa menurut tindakan yang dilakukan atau diperintahkan oleh pelaku perundungan. 
Alberti dan Emmons (2007) mengemukakan bahwa bila perilaku asertif dikembangkan maka kecenderungan perundungan akan menurun. Sullivan, Clearly \& Sullivan (2005) mengemukakan bahwa korban perundungan memiliki perilaku asertif yang rendah, hal ini karena korban perundungan tidak mampu menolak ketika menerima perlakuan yang tidak menyenangkan, tidak percaya diri dan tidak tegas dalam mengemukakan perasaan tidak nyamannya. Keliat, Tololiu, Daulima dan Erawati (2015) mengemukakan bahwa remaja yang kurang mampu berkomunikasi secara asertif cenderung menjadi ekor atau pengikut bagi teman-temannya dan besar kemungkinan menjadi korban perundungan.

Penelitian yang dilakukan oleh Novalia dan Dayakisni (2013) pada siswa 60 MA Lesok Pasuruan menemukan bahwa terdapat korelasi negatif yang signifikan antara perilaku asertif dengan kecenderungan menjadi korban perundungan. Semakin tinggi perilaku asertif maka semakin rendah kecenderungan menjadi objek perundungan, sebaliknya semakin rendah perilaku asertif maka semakin tinggi kecenderungan menjadi objek perundungan. Fox dan Boulton (2005) mengemukakan bahwa korban perundungan tidak mampu menikmati kehidupan sehari-hari disekolah secara normal dan tidak memiliki keterampilan sosial yang mendukung dalam berinteraksi sosial. Objek perundungan cenderung menarik diri, cemas dan menghindari konflik.

Glew, Fan, Katon, Rivara, dan Kercic (2005) mengemukakan bahwa siswa yang menjadi korban perundungan mengalami masalah pada prestasi akademik, merasa tidak nyaman dan aman disekolah, bahkan sedih dan menarik diri. Eisenberg (2006) mengemukakan bahwa anak yang beresiko menjadi korban perundungan yakni yang lebih banyak menghindari perilaku agresif, sering menarik diri dari interaksi sosial, memiliki kecemasan yang tinggi, tidak mampu membela diri dan cenderung pendiam. Rigby (2007) mengemukakan bahwa siswa yang menjadi korban perundungan berdampak pada kesulitan bergaul, menimbulkan rasa tidak nyaman dan takut disekolah, menghindari sekolah berakibat pada ketinggalan pelajaran, dan tak jarang siswa yang sering mendapatkan perlakuan perundungan beresiko melakukan bunuh diri karena tidak mampu dan takut untuk mengkomunikasikan perlakuan yang dialami.

Berdasarkan penjelasan diatas dan didukung oleh penelitian sebelumnya, perilaku perundungan di sekolah berasrama patut mendapatkan perhatian khusus untuk membantu siswa mengembangkan perilaku asertif di lingkungan asrama. Perilaku 
asertif akan mendukung siswa mencegah bahkan melawan perilaku perundungan yang terjadi di lingkungan asrama. Berdasarkan pemaparan di atas maka peneliti tertarik untuk melihat "hubungan antara perilaku asertif dengan kecenderungan menjadi objek perundungan pada remaja berasrama".

\section{METODE}

Metode yang digunakan dalam penelitian ini adalah kuantitatif. Responden penelitian ini sebanyak 205 siswa remaja usia 12-17 tahun dari sekolah berasrama pesantren A dan SMA B. Teknik analisis yang digunakan dalam penelitian ini adalah Spearman rank correlation.

Azwar (2018) mengemukakan bahwa populasi adalah kelompok partisipan yang akan menerima generalisasi hasil penelitian. Populasi dalam penelitian ini adalah siswa yang tinggal di sekolah berasrama A dan B. Azwar (2018) mengemukakan bahwa sampel adalah representasi dari populasi yang memiliki karakteristik partisipan yang sudah ditentukan. Teknik pengambilan sampel yang digunakan dalam penelitian ini adalah accidental sampling. Hadi (2017) mengemukakan bahwa accidental sampling merupakan teknik pengambilan sampel berdasakan spontanitas yakni orang yang ditemui dan sesuai dengan karakteristik subjek akan dijadikan responden penelitian.
Subjek pada penelitian ini yaitu siswa yang tinggal di asrama usia 11-17 tahun. Peneliti memberikan skala penelitian kepada siswa di asrama A dan B yang ditemui secara acak dan bersedia mengisi skala penelitian.

Teknik pengumpulan data dalam penelitian ini menggunakan instrument berupa skala psikologi. Jenis skala yang digunakan dalam penelitian ini adalah skala Likert. Sugiyono (2013) mengemukakan bahwa skala model Likert merupakan model skala yang menggunakan sistem rating untuk mengukur sikap, persepsi dan pendapat individu terkait fonomena sosial. Skala Likert terbagi atas dua jenis aitem yaitu aitem favorable dan unfavorable. Alternatif pilihan jawaban pada skala Likert dapat berupa 4-7 pilihan jawaban. Penelitian ini menggunakan dua skala untuk mengungkap masing-masing variabel yaitu skala perilaku asertif dan skala kecenderungan menjadi objek perundungan. Skala yang disusun oleh peneliti menggunakan rentang skor 0-3. Skala perilaku asertif menggunakan pilihan respon sangat setuju, setuju, tidak setuju, dan sangat tidak setuju. Skala kecenderungan menjadi objek perundungan menggunakan pilihan selalu, sering, jarang dan tidak pernah.

Skala perilaku asertif digunakan untuk mengukur perilaku asertif pada remaja yang bersekolah di asrama. Skala perilaku asertif 
disusun oleh peneliti berdasarkan aspek yang dikemukakan oleh Alberti dan Emmons (2017) aspek perilaku asertif yaitu perilaku berupa ekspresi langsung, tegas dan positif, mempromosikan kesetaraan dalam hubungan antar manusia, bertindak sesuai dengan minat atau keinginan sendiri, membela diri, menjalankan hak pribadi, tidak mengabaikan hak orang lain, dan mengekspresikan kebutuhan dan perasaan secara jujur dan nyaman. Hasil uji coba skala perilaku asertif didapatkan sebanyak 48 aitem yang gugur dan 27 aitem yang dapat digunakan dalam skala perilaku asertif. Koefisien korelasi total pada aitem yang dapat digunakan dalam penelitian ini berada pada rentang angka 0,272 hingga 0,574 .

Skala kecenderungan menjadi objek perundungan digunakan untuk mengukur kecenderungan remaja menjadi objek perundungan. Skala kecenderungan menjadi objek perundungan disusun oleh peneliti berdasarkaan karakteristik yang dikemukakan oleh Sullivan, Cleary dan Sullivan (2005) bahwa objek perundungan mengalami perundungan secara fisik, nonfisik dan perusakan properti. Kecenderungan untuk menjadi objek perundungan terdiri atas dua karakteristik yaitu passive victim dan provocative victims. Passive victim menunjukkan ciri pencemas, cenderung rendah diri, memiliki fisik yang lemah, kurang asertif dan tidak popular. Sedangkan provocative victim menunjukkan ciri bertindak berlebihan, terlalu aktif sehingga memiliki masalah pada konsentrasi dan orang disekitarnya cenderung merasa terganggu degan kehadirannya. Hasil uji coba skala kecenderungan menjadi objek perundungan didapatkan sebanyak 26 aitem yang gugur dan 20 aitem yang dapat digunakan dalam skala kecenderungan menjadi objek perundungan. Koefisien korelasi total pada aitem yang dapat digunakan dalam penelitian ini berada pada rentang angka 0,234 hingga 0,603 .

Berdasarkan hasil uji coba skala penelitian yang dilakukan oleh peneliti terhadap skala yang telah disusun, diperoleh skor reliabilitas 0,876 pada skala perilaku asertif dan 0,857 pada skala kecenderungan menjadi objek perundungan. Hasil tersebut menunjukkan bahwa data yang dikumpulkan pada uji coba skala reliabel. Data uji coba skala diolah dengan menggunakan bantuan aplikasi SPSS 23 for windows.

Setelah mengumpulkan data penelitian pada 205 responden penelitian, didapatkan nilai Cronbach's Alpha 0,794 pada skala perilaku asertif dan 0,808 pada skala kecenderungan menjadi objek perundungan. Nilai tersebut menunjukkan bahwa data penelitian yang dikumpulkan reliabel. 
Analisis data dalam penelitian ini dilakukan dengan bantuan aplikasi menggunakan analisis deskriptif dan uji STATCAL.

hipotesis. Analisis deskriptif data penelitian dilakukan menggunakan bantuan aplikasi Microsoft excel dan SPSS 23 for windows. Uji hipotesis menggunakan analisis Spearman rank correlation dengan dasar pengambilan keputusan jika nilai signifikansi hasil penelitian sama dengan atau dibawah 0,05 maka hubungan kedua variabel signifikan $(p=0,05)$. Uji hipotesis

\section{HASIL DAN PEMBAHASAN}

\section{Hasil}

Responden yang dilibatkan dalam penelitian ini adalah remaja usia 11-17 tahun yang berstatus sebagai siswa di sekolah berasrama. Berikut merupakan gambaran responden berdasarkan usia dan jenis kelamin:

Tabel 1. Kategorisasi Responden Berdasarkan Jenis Kelamin

\begin{tabular}{ccc}
\hline Jenis Kelamin & Jumlah & Persentase (\%) \\
\hline Laki-Laki & 114 & 56 \\
Perempuan & 91 & 44 \\
\hline Jumlah & 205 & 100 \\
\hline \multirow{2}{*}{ Berdasarkan tabel diatas diketahui } & ini sebanyak 205 orang yang terdiri dari \\
bahwa jumlah responden dalam penelitian & 114 orang (56\%) laki-laki dan 91 orang \\
& \multicolumn{2}{|c|}{ (44\%) perempuan. }
\end{tabular}

Gambar 1. Kategorisasi Responden Berdasarkan Usia

12 tahun

- 13 tahun

14 tahun

15 tahun

16 tahun

17 tahun

\section{USIA RESPONDEN}

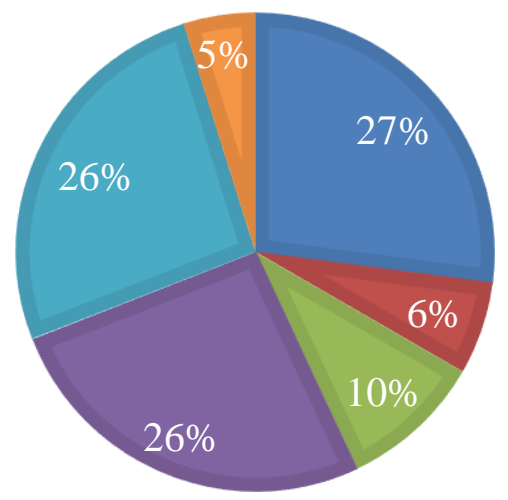


Berdasarkan gambar diatas diketahui rentang usia responden berada pada 12-17 tahun. Responden dengan usia 12 tahun sebanyak 54 orang (26\%), usia 13 tahun sebanyak 13 orang (6\%), usia 14 tahun sebanyak 20 orang (10\%), usia 15 tahun sebanyak 54 orang (26\%), usia 16 tahun sebanyak 54 orang (26\%), dan usia 17 tahun sebanyak 10 orang (5\%).

Tabel 2. Kategorisasi Skor Skala Perilaku Asertif

\begin{tabular}{ccccc}
\hline Variabel & Skor & Frekuensi & Persentase(\%) & Kategori \\
\hline \multirow{2}{*}{ Perilaku Asertif } & $63,6 \leq \mathrm{X}_{1}$ & 32 & 16 & Tinggi \\
$\left(\mathrm{X}_{1}\right)$ & $46,8 \leq \mathrm{X}_{1}<63,6$ & 147 & 72 & Sedang \\
& $\mathrm{X}_{1}<46,8$ & 26 & 13 & Rendah \\
\hline \multicolumn{2}{c}{ Jumlah } & 205 & 100 & \\
\hline
\end{tabular}

Berdasarkan tabel 2 pada skala responden berada pada kategori sedang perilaku asertif menunjukkan bahwa 32 dengan persentase $72 \%$ dan sebanyak 26 responden berada pada kategori tinggi responden berada pada kategori rendah dengan persentase $16 \%$, sebanyak 147 dengan persentase $13 \%$.

Tabel 3. Kategorisasi Skor Skala Kecenderungan Menjadi Objek Perundungan

\begin{tabular}{ccccc}
\hline Variabel & Skor & Frekuensi & Persentase(\%) & Kategori \\
\hline Kecenderungan & $23,6 \leq \mathrm{X}_{1}$ & 40 & 20 & Tinggi \\
Menjadi Objek & $8,0 \leq \mathrm{X}_{1}<23,6$ & 134 & 65 & Sedang \\
Perundungan $\left(\mathrm{X}_{2}\right)$ & $\mathrm{X}_{1}<8,0$ & 31 & 15 & Rendah \\
\hline Jumlah & & 205 & 100 & \\
\hline
\end{tabular}

Berdasarkan tabel 3 hasil kategorisasi variabel kecenderungan menjadi objek perundungan menunjukkan bahwa sebanyak 40 responden berada pada kategori tinggi dengan persentase $20 \%$, sebanyak 134 responden berada pada kategori sedang dengan persentase $65 \%$ dan sebanyak 31 responden berada pada kategori rendah dengan persentase $15 \%$.

Tabel 4. Hasil Uji Hipotesis

\begin{tabular}{cccc}
\hline Variabel & Koefisien Korelasi & Signifikansi & Keterangan \\
\hline Perilaku Asertif & $-0,22$ & 0,002 & Signifikan \\
$\begin{array}{c}\text { Kecenderungan Menjadi } \\
\text { Objek Perundungan }\end{array}$ & & & \\
\hline
\end{tabular}

Hasil uji hipotesis menunjukkan bahwa nilai koefisien korelasi $-0,22$ dan nilai signifikansi 0,002 . Berdasarkan nilai koefisien korelasi yang ditemukan berada 
pada rentang angka 0-1 dan bersifat negatif, maka kedua variabel memiliki hubungan negatif. Berdasarkan hasil tersebut maka Ha diterima, artinya terdapat hubungan antara perilaku asertif dengan kecenderungan menjadi objek perundungan pada siswa berasrama. Semakin tinggi perilaku asertif semakin rendah kecenderungan menjadi objek perundungan, begitupun sebaliknya. Kaidah signifikansi yang digunakan dalam penelitian ini adalah jika nilai signifikansi hasil penelitian $<0,05$ maka hubungan kedua variabel signifikan. Berdasarkan nilai signifikansi yang ditemukan yaitu $0,002<0,05$, maka hubungan antara kedua variabel signifikan.

\section{Pembahasan}

Berdasarkan hasil analisis deskriptif menunjukkan bahwa sebagian besar siswa berasrama memiliki tingkat perilaku asertif pada kategori sedang. Data tersebut menunjukkan bahwa 32 siswa (16\%) memiliki perilaku asertif yang tinggi, 147 siswa $(72 \%)$ memiliki perilaku asertif pada kategori sedang, dan 26 siswa (13\%) memiliki perilaku asertif yang rendah.

Alberti dan Emmons (2017) mengemukakan bahwa perilaku asertif merupakan kemampuan individu untuk mengekspresikan diri secara tegas dan positif dengan tetap menghargai hak orang lain. Perilaku asertif digunakan untuk memenuhi kebutuhan dan membela diri secara jujur tanpa perasaan cemas. Siswa yang mampu berperilaku asertif secara umum mampu menyatakan perasaan dengan nyaman untuk mempertahankan diri serta memenuhi kebutuhan. Berdasarkan hasil penelitian ini sebagian besar memiliki tingkat perilaku asertif yang sedang menandakan bahwa sebagian besar siswa dapat menunjukkan perilaku asertif yang cukup. Hal ini dapat dilihat dari respon yang dicantumkan pada skala yang diisi oleh siswa. Aitem dengan skor tertinggi menyatakan bahwa siswa terbiasa mencium tangan ketika bertemu dengan guru. Alberti dan Emmons (2017) mengemukakan bahwa perilaku asertif mendorong individu untuk berinisiatif membangun komunikasi dan mengungkapkan perasaan dengan menghargai orang lain.

Salah satu aitem dengan skor tinggi menyatakan bahwa siswa akan membela diri jika teman menghina atau meremehkan. Aitem lain dengan skor yang cukup tinggi menyatakan bahwa siswa akan menyatakan tidak setuju kepada senior yang melakukan pemukulan. Hasil tersebut sejalan dengan teori yang dikemukakan oleh Ames (2008) bahwa perilaku asertif adalah kemampuan mengemukakan perasaan untuk memenuhi 
kebutuhan, membela dan mengusahakan kepentingan pribadi serta mampu menolak hal yang berlawanan dengan persepsi pribadi. Perilaku asertif menunjukkan kemampuan individu dalam memenuhi hak pribadi dengan tetap mempertimbangkan perasaan dan pendapat untuk menghargai perasaan dan persepsi orang lain.

Perilaku asertif mendorong individu untuk berani menyatakan pendapat terhadap sebuah pelanggaran. Salah satu aitem perilaku asertif memiliki skor yang tinggi menyatakan bahwa siswa akan diam saja meskipun tahu teman kabur dari asrama, aitem lainnya menyatakan bahwa siswa akan membiarkan senior melakukan kesalahan agar terhindar dari masalah. Sebagian besar siswa memberi pernyataan tidak setuju dan sangat tidak setuju. Alberti dan Emmons (2017) menyatakan bahwa indvidu yang asertif mampu memberikan tanggapan dan pernyataan tidak setuju secara jujur dan nyaman terhadap pelanggaran terhadap diri maupun orang lain.

Perilaku asertif lain juga nampak dalam keseharian pada siswa berasrama yang dilihat oleh peneliti selama berada dilokasi penelitian. Para siswa saling tolong menolong tanpa ada yang meminta tolong menginstruksikan untuk menolong. Alberti dan Emmons (2017) mengemukakan bahwa individu yang berperilaku asertif aktif berpartisipasi secara sosial dengan memberikan bantuan kepada orang yang membutuhkan meskipun tanpa diminta.

Benítez dan Justicia (2006) mengemukakan bahwa perundungan merupakan perilaku dengan sengaja mengintimidasi untuk merugikan orang lain. Perundungan melibatkan ketidakseimbangan kekuasaan antara dua pihak dan terjadi baik secara langsung dan tidak langsung. Berdasarkan hasil analisis deskriptif data penelitian menunjukkan bahwa siswa berasrama memiliki kecenderungan menjadi objek perundungan pada kategori sedang. Data hasil penelitian menunjukkan bahwa sebanyak 40 siswa (20\%) memiliki tingkat kecenderungan menjadi objek perundungan pada kategori tinggi, 134 siswa (65\%) memiliki tingkat kecenderungan menjadi objek perundungan pada kategori sedang dan 31 siswa (15\%) memiliki tingkat kecenderungan menjadi objek perundungan pada kategori rendah. Olweus (2010) mengemukakan bahwa individu dikategorikan sebagai objek perundungan jika menerima perlakuan penindasan sehinga merasa tersakiti dan tidak mampu membela diri.

Berdasarkan hasil analisis deskriptif data penelitian menunjukkan bahwa sebagian besar siswa memiliki tingkat 
kecenderungan menjadi objek perundungan pada kategori sedang. Hasil analisis deskriptif pada aspek mengalami perundungan ditemukan bahwa sebagian besar siswa mengalami perundungan fisik pada kategori sedang dengan persentase sebesar 54\%. Perundungan fisik yang dialami oleh siswa diantaranya didorong dan dijambak dilingkungan sekolah. Hal tersebut sesuai dengan teori yang dikemukakan oleh Sullivan, Cleary dan Sullivan (2005) bahwa beberapa bentuk perundungan fisik yang sering terjadi pada siswa yaitu digigit, dipukul, dicakar, dilempari, ditampar, disandung, rambutnya ditarik dan penyerangan secara fisik lainnya.

Aitem dari perundungan fisik merupakan salah satu aitem dengan skor tertinggi, pada pernyataan saya dijaga oleh teman-teman agar tidak dipukul oleh senior. Skor tinggi tersebut sejalan dengan obrolan singkat yang dilakukan oleh peneliti dengan responden bahwa sering terjadi pemukulan di asrama, namun dianggap biasa saja karena sudah menjadi budaya meskipun meninggalkan perasaan tidak nyaman pada responden. Responden mengaku malas melaporkan pada pihak sekolah karena dianggap sebagai upaya untuk mendisiplinkan dan memberi motivasi untuk taat aturan disekolah. Sesuai dengan teori yang dikemukakan oleh Sullivan, Cleary dan Sullivan (2005) yang menyatakan bahwa salah satu yang mempengaruhi individu cenderung menjadi objek perundungan adalah karena tidak berani memberitahu orang lain tentang perlakuan yang dialami. Objek perundungan tidak percaya guru dapat menghentikan perlakuan intimidasi dan tidak ingin membuat orang tua khawatir.

Berdasarkan hasil analisis deskriptif kategorisasi skor perundungan verbal diketahui bahwa sebagian besar siswa mengalami perundungan verbal pada kategori sedang dengan persentase $54 \%$. Perundungan verbal yang dialami oleh siswa yaitu difitnah, diejek dan dipanggil dengan sapaan yang tidak disenanginya. Perlakuan tersebut sesuai dengan bentuk perundungan yang dikemukakan oleh Olweus (2010) bahwa objek perundungan mengalami gertakan kasar, dipanggil dengan panggilan yang kejam dan menyakitkan, diolok-olok, serta menyebarnya berita bohong tentang objek perundungan.

Berdasarkan hasil analisis deskriptif kategorisasi skor perundungan nonverbal direct diketahui bahwa sebagian besar siswa mengalami perundungan nonverbal direct pada kategori sedang dengan persentase sebesar 52\%. Perundungan 
nonverbal direct yang dialami siswa di asrama berupa disindir dan diteriaki ketika lewat didepan senior. Bentuk perundungan ini sesuai dengan yang dikemukakan oleh Sullivan, Cleary dan Sullivan (2005) bahwa perundungan nonverbal langsung terjadi dalam bentuk gerakan kasar, tatapan sinis dan biasanya disertai dengan perundungan verbal atau fisik. Bentuk penindasan ini seringkali tidak dianggap sebagai perundungan karena dianggap tidak berbahaya.

Berdasarkan hasil analisis deskriptif kategorisasi skor perundungan nonverbal indirect diketahui bahwa sebagian besar siswa mengalami perundungan nonverbal indirect pada kategori sedang dengan persentase sebesar 70\%. Perundungan dialami dalam bentuk dikucilkan, diabaikan oleh teman diasrama, dan seseorang menghasut orang lain untuk membencinya. Perlakuan ini sesuai dengan pendapat yang dikemukakan oleh Olweus (2010) bahwa perundungan tidak langsung yang sering diterima oleh objek perundungan yaitu berupa pengabaian, pengucilan dan penghindaran dari kelompok sebaya secara sengaja dan membuat siswa lain tidak menyukai objek perundungan. Skor tertinggi pada skala kecenderungan menjadi objek perundungan terdapat pada aitem dengan pernyataan teman saya mengabaikan segala penilaian buruk tentang saya dari orang lain. Artinya kebanyakan siswa merasa dibenci oleh teman karena hasutan orang lain. Benítez dan Justicia (2006) mengemukakan bahwa objek perundungan cenderung rendah diri, merasa dibenci dan ditolak secara sosial.

Berdasarkan hasil analisis deskriptif kategorisasi skor perundungan dalam bentuk perusakan barang, sebagian besar siswa berada pada kategori sedang dengan persentase sebesar $67 \%$. Perlakuan yang diterima dalam bentuk barang milik diambil tanpa izin atau dirusak oleh senior. Sesuai dengan teori yang dikemukakan oleh Sullivan, Cleary dan Sullivan (2005) bahwa perundungan dapat terjadi dalam bentuk perusakan barang milik berupa perusakan buku, pakaian, penghancuran barang dan barang milik diambil tanpa persetujuan. Salah satu aitem dengan skor tinggi pada skala kecenderungan menjadi objek perundungan yaitu aitem yang menyatakan bahwa barang saya diambil tanpa izin dan tidak dikembalikan. Selain itu peneliti sempat menanyakan apakah siswa sering kehilangan barang diasrama, dan responden mengakui barangnya sering dipinjam oleh senior tanpa izin dan kadang tidak dikembalikan hingga akhirnya tidak diketahui keberadaannya. 


\section{PENUTUP}

Berdasarkan hasil analisis uji hipotesis dari penelitian ini dapat disimpulkan bahwa ada hubungan negatif antara perilaku asertif dengan kecenderungan menjadi objek perundungan pada siswa berasrama ( $p=-0,22 r=0,002)$. Semakin tinggi tingkat perilaku asertif maka semakin rendah kecenderungan menjadi objek perundungan pada siswa berasrama. Sebaliknya, semakin rendah perilaku asertif maka semakin tinggi kecenderungan menjadi objek perundungan pada siswa berasrama.

Berdasarkan hasil penelitian yang dilakukan, peneliti menyimpulkan beberapa saran sebagai berikut:

1. Penelitian selanjutnya diharapkan lebih menggali faktor-faktor lain yang mempengaruhi perundungan di lingkungan asrama seperti sistem disekolah dan persepsi terkait perundungan. Selain itu penelitian selanjutnya dapat menggunakan metode kualitatif untuk mengungkap aspek psikologis subjek yang mengalami dampak negatif berat akibat perundungan.

2. Bagi siswa diharapkan dapat mengembangkan dan lebih percaya diri dalam menunjukkan perilaku asertif agar terhindar dari perlakuan tidak menyenangkan di lingkungan sekolah sehingga dapat nyaman menjalani pendidikan di sekolah berasrama.

3. Penelitian ini diharapkan sebagai evaluasi agar orang tua dapat lebih membiasakan perilaku asertif pada anak serta lebih berinisiatif untuk mengetahui permasalahan yang dihadapi anak di sekolah dan di asrama.

4. Penelitian ini diharapkan dapat menjadi dasar pengembangan program untuk mengembangkan perilaku asertif pada siswa dan juga sebagai evaluasi untuk lebih memperhatikan masalah perundungan yang terjadi di lingkungan sekolah dan asrama.

\section{DAFTAR PUSTAKA}

Alberti, R. \& Emmons, M. (2017). Your perfect right: Assertiveness and equality in your live and relationship. $10^{\text {th }}$ Ed. Oakland: Impact Publisher, New Harbinger Publications, Inc.

Amesh, D.R. (2008). Insearch of the right touch: Interpersonal assertive in organizational life. Broadway, New York: Columbia Business School.

Arif, F. \& Wahyuni, S. (2017). Hubungan kelektan pada ibu, ayah dan teman sebaya dengan kecenderungan anak menjadi pelaku dan korban bullying. Jurnal psikologi ulayat. 4(2): 122-140. DOI 10.24854/jpu22017-100.

Atkinson, J.M. (1997). Pengantar psikologi. $11^{\text {th }}$ Ed. Jilid 1. Batam: Interaksara.

Azwar, S. (2018). Metode penelitian psikologi. Edisi II. Yogyakarta: Pustaka Pelajar. 
Benítez, J.L., \& Justicia, F. (2006). Bullying: description and analysis of the phenomenon. Electronic Journal of Research in Educational Psychology. 4(2): 151-170. ISSN: 169-2095.

Coloros, B. (2003). Stop bullying: memutuskan rantai kekerasan anak prasekolah hingga SMU. Jakarta: PT Serambi Ilmu Semesta.

Eisenberg, N. (2006). Empathy-related responding and prosocial behaviour. Hoboken, NJ: John Wiley \& Sons.

Fox, C.L., \& Boulton, M.J. (2005). The social skill problems of victims of bullying: self, peer and teacher perceptions. British Journal of Educational Psychology, 75: 313-328. DOI:10.1348/000709905X25517.

Glew, G. M., Fan, M. -Y., Katon, W., Rivara, F. P., \& Kernic, M. A. (2005). Bullying, psychosocial adjustment, and academic performance in elementary school. Arch Pediatr Adolesc Med, 159, 1026-1031.

Hadi, S. (2017). Statistik. (Edisi Revisi). Yogyakarta: Pustaka Pelajar.

Hurlock, E.B. (1980). Psikologi perkembangan: suatu pendekatan sepanjang rentang kehidupan. $5^{\text {th }} \mathrm{Ed}$. Jakarta: Erlangga.

Karyanti, Atmoko, A., Hitipeuw, I. (2015). Keefektifan pelatihan keterampilan asertif untuuk meningkatkan perilaku asertif siswa korban bullying di SMA. Jurnal Pendidikan Humaniora. 3(2): 116-121.

Keliat, B.A., Tololiu, T.A., Daulima, N.H.C. \& Erawati, E. (2015). Effectiveness assertive training of bullying prevention among adolescents in West Java Indonesia. International journal of nourishing, 2(1): 128-134. DOI.10.15640/ijn.v2n1a14.

Meilena, T. \& Suryanto. (2015). Self disclosure, perilaku asertif dan kecenderungan terhindar dari tindakan bullying. Persona, Jurnal Psikologi Indonesia. 4(2): 208-215.
Novalia \& Dayakisni, T. (2013). Perilaku asertif dan kecenderungan menjadi korban bullying. Jurnal ilmiah psikologi terapan, 1(1): 172-178.

Olweus, D. (2004). Bullying at school. Australia: Blackwell publishing.

Olweus, D. (2010). Understanding and researching bullying: some critical issues. In Jimerson, S.R., Swearer, S.M., \& Espelage, D.L. Handbook of bullying in schools: an international perpective (pp. 1-6). Abingdon, Oxon, UK: Routledge, Taylor and Francis.

Pratiwi, P., \& Sari, S. (2017). Perilaku bullying pada sekolah asrama di banda aceh.

Online. http://www.jim.unsyiah.ac.id/FKep/arti cle/viewFile/3908/3053. Diakses pada 4 Februari 2018.

Putri, H. N., Nauli, F.A., \& Novayelinda, R. (2015). Faktor-faktor yang berhubungan dengan perilaku bullying pada remaja. JOM Pogram Studi Ilmu Keperawatan Universitas Riau, 2(2): 1149-1159.

Rasyid, M. (2012). Hubungan antara peer attachment dengan regulasi emosi remaja yang menjadi siswa di boarding school SMA Negeri 10 Samarinda. Jurnal Psikologi Pendidikan dan Perkembangan. 1(3): 01-07.

Rigby, K. (2007). Bullying in school. And what to do about it. In E. Webb (Ed). Desind and typography, ACER Press 2007. An Imprint of Australian Council for Educational Research Ltd19 Prospect Hill Road, Camberwell Victoria, 3124, Australia.

Santrock, J.W. (2003). Adolescence: perkembangan remaja. $6^{\text {th }}$ Ed. Jakarta: Erlangga.

Sriyanto, Abdulkarim, A., Zainul, A., Maryani, E. (2014). Perilaku asertif dan kecenderungan kenakalan remaja berdasarkan pola asuh dan peran media massar. Jurnal Psikologi, 41(1): 74-88. 
Sugiyono. (2013). Metode penelitian kuantitatif, kualitatif dan $R \& D$. Bandung: Alfabeta.
Sullivan, K., Clearly, M. \& Sullivan, G. (2005). Bullying in secondary school: what it loks like and how to manage it. Thousand Oaks, CA: Crowing Press. 